DUNAMIS (Jurnal Teologi dan Pendidikan Kristiani)

Volume 2, Nomor 1 (Oktober 2017)

ISSN 2541-3937 (print), 2541-3945 (online)

http://www.sttintheos.ac.id/e-journal/index.php/dunamis

Submitted: 27 Mei 2017

Accepted: 31 Oktober 2017

Published: 31 Oktober 2017

\title{
Memahami Kesia-sian dalam Kitab Pengkhotbah
}

\author{
Yohanes Krismantyo Susanta \\ Sekolah Tinggi Agama Kristen Negeri Toraja \\ yohanessusanta@gmail.com
}

\begin{abstract}
This paper is an attempt to understand a phrase in the book of Ecclesiastes which is oftenmisunderstood that "a lot of learning makes the body to be weary." Using the biblical approach, it argued that the tone of skepticism in the book needs to be re-understood. The phrase does not justify the lazy nature; Instead it becomes a rebuke and an invitation for believers not to rely on human reason and wisdom but to rely on God, the owner of life.
\end{abstract}

Keywords: Ecclesiastes; gift; meaningless; study

\begin{abstract}
Abstrak
Tulisan ini merupakan usaha memahami sebuah ungkapan dalam kitab pengkhotbah yang seringkali disalahpahami yaitu "banyak belajar melelahkan badan." Dengan memanfaatkan pendekatan biblika, saya berpendapat bahwa nada skeptis dalam kitab ini perlu dipahami ulang. Ungkapan tersebut tidak membenarkan sifat malas; justru ia menjadi teguran sekaligus ajakan bagi orang beriman agar tidak mengandalkan akal budi dan hikmat manusia melainkan tetap bersandar kepada Allah, sang pemilik kehidupan.
\end{abstract}

Kata Kunci: karunia; belajar; kitab Pengkhotbah; kesia-siaan 


\section{PENDAHULUAN}

Setiap orang yang gemar menonton film baik berjenis drama, komedi, film action maupun yang bertema super hero, dengan mudah dapat menebak ujung cerita. Meskipun pembaca atau penonton tidak dapat menebak dengan pasti jalannya cerita-karena penulis atau sutradara mengemasnya sedemikian rupa-akan tetapi pada umumnya, pembaca atau penonton dapat menebak bahwa kisah tersebut pasti akan berakhir dengan happy ending. Penjahat yang sebenarnya, betapapun cerdik dan hebat, pasti akan mendapat hukuman, sementara sang jagoan akan tampil sebagai pemenang. Singkatnya, Kebaikan akan selalu menang atas kejahatan; sebuah akhir yang bahagia. Itu sebabnya, sebuah kalimat penutup dalam film atau buku cerita yang sangat klise seringkali berkumandang: and they lived happily ever after. Sebuah akhir cerita yang terdengar tidak asing, bukan?

Tidak dapat dipungkiri bahwa akhir cerita yang mudah ditebak membuat sebagian orang enggan untuk menghabiskan uang untuk membeli buku cerita atau menonton film di bioskop. Akan tetapi, kenyataan tersebut nyatanya tidak menyurutkan semangat para sutradara, penulis, dan produser film untuk berlombalomba dalam menyajikan film-film terbaru yang berkualitas. Bahkan, Penulis skenario juga tertantang membuat cerita yang benarbenar tidak mudah, bahkan tidak dapat ditebak. Film berjudul Nightcrawler menjadi salah contoh. Film tersebut menawarkan sesuatu yang berbeda. Cerita yang dibuat tidak hanya membuat penonton penasaran karena jalannya cerita yang cukup sulit ditebak, tetapi juga menyajikan akhir cerita yang "tidak biasa." Bahkan bagi sebagian orang, mungkin, akhir cerita tersebut "mengecewakan."

Kisah yang ditawarkan oleh penulis skenario film di atas sangat berbeda dan cenderung bertentangan dengan semangat yang dimunculkan dalam film-film populer. Menariknya, semangat yang hampir sama dapat kita temukan juga dalam Alkitab kita. Kenyataannya, banyak orang Kristen senang membaca Firman Tuhan yang tertulis dalam Amsal, misalnya pada pasal 6 yang acapkali dipakai untuk mengajar dan memberi nasihat agar manusia belajar dari kerajinan semut dan menjauhi kemalasan para belalang. Orang juga senang membaca Mazmur 1 yang berisi keyakinan bahwa orang benar akan diberkati dan orang fasik akan mendapat kemalangan serta hukuman, bahkan kebinasaan. Singkatnya, ada banyak ayat dalam Alkitab yang bernada sangat optimis. Ada beberapa ayat firman Tuhan yang sering dipakai para penulis renungan, pengkotbah dan motivator untuk membangkitkan semangat para pendengar 
dan para pembaca. Itu sebabnya banyak orang mengatakan bahwa Firman Tuhan yang tertuang dalam Alkitab menyediakan jawaban dan jalan keluar, menyediakan nasihat dan penghiburan yang nyata bagi setiap orang.

Akan tetapi, hal sebaliknya justru kita jumpai dalam kitab Pengkhotbah. Para pembaca Alkitab yang kritis dengan segera akan menemukan kesan pesimis dan skeptik yang mewarnai kitab Pengkhotbah. ${ }^{1}$ Kitab Pengkhotbah menyajikan sesuatu yang tidak biasa, tidak seperti kitab-kitab lain pada umumnya. Dalam tulisan ini, penulis akan memusatkan perhatian pada salah satu frasa yang mengatakan, "...banyak belajar melelahkan badan" (Pkh. 12:12). Akan tetapi pada bagian awal dari tulisan ini, terlebih dahulu kita akan melihat secara umum isi kitab Pengkotbah yang tidak biasa itu.

\section{Isi Kitab yang "Tidak Biasa"}

Sebagian besar orang Indonesia tentu mengenal pepatah yang mengatakan "rajin pangkal pandai, hemat pangkal kaya." Sejak duduk di bangku Sekolah Dasar, penulis sudah mengenal peribahasa tersebut. Peribahasa itu sangat terkenal dan tetap dipelihara sampai sekarang serta diturunalihkan kepada generasi selanjutnya.

\footnotetext{
${ }^{1}$ Tremper Longman III dan Raymond B. Dillard, An Introduction to the Old Testament, 2nd ed. (Grand Rapids: Zondervan, 2006), 278.
}

Sebagian besar mengamini dan menerimanya begitu saja tanpa protes. Anehnya, peribahasa tersebut seolah-olah tidak berlaku bagi penulis kitab Pengkhotbah ketika ia mengatakan, "banyak belajar melelahkan badan." Apakah tulisan tersebut merupakan jerit hati seorang yang mengalami trauma sebagai anak dari keluarga Israel yang dipaksa belajar oleh orangtuanya? Lalu mengapa teks ini (dan tulisan lain yang sejenis) lulus sensor dan menjadi bagian dari kanon Alkitab? Bukankah teks ini mendukung sifat malas yang sangat bertentangan nilai-nilai yang dianut dan ditanamkan oleh keluarga Israel dan tentunya pembaca masa kini? Bukankah ini juga bertentangan dengan harapan dan dorongan yang disematkan pada setiap pelajar dan mahasiswa agar rajin belajar? Dalam pengalaman penulis saat menjadi mahasiswa Sekolah Teologi, kutipan yang diambil dari kitab Pengkhotbah ini juga sering dicatut (sebagai bahan candaan) sebagai pembenaran untuk menunda tugas dan bermalas-malasan.

Sebagai pembaca, hendaknya kita tidak buru-buru menyampaikan tuduhan tersebut. Dalam hal ini berlaku asa praduga tidak bersalah terhadap kitab Pengkhotbah. Meski demikian, secara jujur dan terbuka, beberapa hal perlu untuk dijelaskan terlebih dahulu. Menurut Jarot Hadianto, 
Gagasan yang ditawarkan kitab Pengkhotbah memang melawan arus dan tampak tidak lazim. Suasan suram, murung, dan pesimis dalam kitab ini bertebaran di mana-mana. Akibatnya, membaca kitab pengkhotbah justru membuat optimisme dan semangat hidup kita melayang pergi. Ini aneh, sebab yang kita baca adalah Kitab Suci! ${ }^{2}$

Dalam pasal-pasal pertama dalam kitab Pengkhotbah, pembaca memang dibuat kebingungan dengan pernyataan demi pernyataan dari Pengkhotbah yang tidak biasa. Setelah memperkenalkan dirinya sebagai anak Daud, raja di Yerusalem (Pkh. 1:1), pengkhotbah memulai kitab ini dengan mengatakan bahwa "segala sesuatu adalah sia-sia” (Pkh. 1:2). Di dalam Alkitab Bahasa Indonesia Terjemahan Baru yang diterbitkan oleh Lembaga Alkitab Indonesia (ITB-LAI), kata "sia-sia" muncul sebanyak 86 kali dan dalam kitab pengkhotbah saja, kata tersebut muncul sebanyak 15 kali. $^{3}$ Dengan demikian, ungkapan "kesia-siaan" mendominasi dan dapat ditemukan hampir di seluruh bagian pasal dalam kitab tersebut. Dan segala sesuatu bagi Pengkhotbah adalah kesia-siaan.

Jika dalam berbagai kesempatan, para pembaca sering menjumpai orang yang hendak berkhotbah berdoa memohon hikmat agar dapat menguraikan Firman Tuhan dengan baik, Pengkhotbah telah

\footnotetext{
${ }^{2}$ Jarot Hadianto, "Banyak Belajar Melelahkan Badan," Wacana Biblika Vol.9, no. 1, Januari-Maret (2009).

${ }^{3}$ Pengkhotbah $1: 2 ; 2: 1,15,19,23 ; 3: 19 ; 5: 7,10 ;$ $6: 12 ; 7: 6,15 ; 8: 10,14 ; 9: 9 ; 12: 8$
}

lebih dulu mengatakan, "Aku telah membulatkan hatiku untuk memahami hikmat dan pengetahuan, kebodohan dan kebebalan. Tetapi aku menyadari bahwa hal inipun adalah usaha menjaring angin" (Pkh. 1:17). Ketika seorang bekerja dengan keras membanting tulang untuk hidup yang lebih baik, Pengkhotbah malah berkata,

Ketika aku meneliti segala pekerjaan yang telah dilakukan tanganku dan segala usaha yang telah kulakukan untuk itu dengan jerih payah, lihatlah, segala sesuatu adalah kesia-siaan dan usaha menjaring angin; memang tak ada keuntungan di bawah matahari... Aku membenci segala usaha yang kulakukan dengan jerih payah di bawah matahari, sebab aku harus meninggalkannya kepada orang yang datang sesudah aku . (Pkh. 2:11, 18).

Lebih lanjut Pengkhotbah juga mengatakan bahwa kekayaan manusia itu pun sia-sia (Pkh. 5:7-6:12). Menurut Pengkhotbah, hidup itu tidak adil. Ada orang yang bekerja dengan keras dengan mencurahkan segala daya dan upayanya untuk masa depan yang gemilang. Tetapi tiba-tiba kematian datang. Apa yang terjadi dengan semua yang sudah diusahakan? Lenyap tak bersisa, dan menjadi sia-sia. Manusia tidak dapat menikmatinya. Bahkan, jauh sebelumnya Pengkhotbah dengan berani mengatakan, "Oleh sebab itu aku membenci hidup, karena aku menganggap menyusahkan apa yang dilakukan di bawah matahari, sebab segala sesuatu adalah kesia-siaan dan usaha menjaring angin" (Pkh. 2:17). Pengkhotbah 
seolah setuju dengan Ayub yang mengutuki hari kelahirannya sendiri (Ayb. 3:11-13). Keunikan dan ketidakbiasaan tersebut oleh banyak ahli dianggap sebagai hal yang menarik karena isi kitab tersebut sangat menantang dan "mengganggu"serta karena kitab tersebut sangat berbeda dengan kitabkitab lainnya. Mungkin karena alasan itu juga yang membuat kitab ini hanya sekali dikutip di Perjanjian Baru (Rm. 3:10). ${ }^{4}$ Akan tetapi pertanyaannya adalah: Apakah benar demikian? Jika hidup ini sia-sia, lalu untuk apa manusia hidup?

\section{Perenungan Panjang tentang Hidup ala Pengkhotbah}

Nama kitab ini adalah "Ecclesiastes" yang diambil dari Septuaginta (LXX) yang berarti "perkumpulan." Dalam bahasa Ibrani "qohelet" yang berasal dari kata benda "qahal" (perkumpulan). Dan "qohelet" berarti orang yang berbicara dalam suatu sidang atau perkumpulan. ${ }^{5}$ Menurut John J. Collins, cukup sulit untuk mengidentifikasi sosok Qohelet tersebut. Meskipun Pengkhotbah menyebut diri sebagai raja di Yerusalem yang sering diasosiasikan dengan Salomo, tampaknya identifikasi tersebut merupakan sebuah fiksi (perdebatan mengenai masalah penulisan

\footnotetext{
${ }^{4}$ Craig G. Bartholomew, Ecclesiastes (Philadelphia: Baker Academic, 2014), 20.

${ }^{5}$ Walter Brueggemann and Tod Linafelt, $A n$ Introduction to the Old Testament: The Canon and Christian Imagination (Louisville: Westminster John Knox Press, 2012), 362.
}

kitab ini akan dijelaskan lebih lanjut pada bagian selanjutnya). ${ }^{6}$ Dapat dikatakan bahwa penulis kitab ini anonim dan merupakan kumpulan tulisan yang tidak berasal dari satu penulis tunggal. Hal yang sama juga diungkapkan oleh Gerrit Singgih yang mengutip Michael Fox bahwa Qohelet adalah tokoh utama dalam kitab ini tetapi tidak harus dianggap historis. Hal yang paling penting adalah bagaimana ia digambarkan, bukan kapan dia hidup. ${ }^{7}$ Cukuplah untuk menyebutnya sebagai orang bijaksana yang menamakan diri sebagai Qohelet yang berasal dari Yerusalem. Pesan atau isi kitab itulah yang paling penting sebagaimana yang dikatakan oleh Bruegemann dan Linafelt bahwa, "the substance of the book is a collection of wisdom sayings and teachings that ponder the mystery of creation and life in the world." 8

Sebenarnya kitab ini tidak berisi khotbah, tetapi lebih kepada sebuah refleksi dari sang Qohelet atau Pengkhotbah. Itu sebabnya, tidak seperti kitab Amsal, kitab Pengkhotbah tidak berisi nasihat-nasihat praktis yang dapat langsung diterapkan

\footnotetext{
${ }^{6}$ John Collins, "Proverbs and Ecclesiastes," in Knox Preaching Guides, ed. John H. Hayes (Atlanta: John Knox Press, 1980), 71.

${ }^{7}$ Emanuel Gerrit Singgih, Hidup Di Bawah Bayang-Bayang Maut: Sebuah Tafsiran Kitab Pengkhotbah (Jakarta: PK Gunung Mulia, 2001), 5.

${ }^{8}$ Brueggemann and Linafelt, An Introduction to the Old Testament: The Canon and Christian Imagination, 363.
} 
dalam kehidupan. Qohelet atau Pengkhotbah menyampaikan sejumlah renungan dalam kehidupan ini sehingga dapat dikatakan bahwa tidak ada khotbah dalam kitab Pengkhotbah. ${ }^{9}$ Qohelet adalah orang yang bergumul dengan dirinya sendiri sebagai seorang bijaksana yang terus bergumul dalam menghadapi realita hidup.

Setiap orang pasti pernah merenung dan berkhayal. Manusia memiliki kebebasan sekaligus hak untuk merenung tanpa perlu diatur dan diketahui oleh orang lain. Manusia dapat merenungkan apa saja dalam batinnya. Demikian pula dengan Qohelet atau sang Pengkhotbah. Ia merenung. Merenungkan hidup ini. Dalam perenungannya yang panjang tentang hidup ini, Pengkhotbah menyebut segala sesuatu adalah sia-sia.

Pada bagian awal dari tulisan ini telah disinggung bahwa pembaca Alkitab yang kritis dan teliti akan menemukan hal-hal yang cukup mengganggu karena nada skeptis dan pesimis yang dengan mudah dapat dijumpai dalam kitab ini. Dalam sejarah penafsiran, isi kitab Pengkhotbah memang seringkali disalahpahami karena nuansa skeptik yang termuat di dalamnya. ${ }^{10}$ Kekeliruan dalam memahami isi kitab Pengkhotbah juga pernah dilakukan oleh

\footnotetext{
${ }^{9}$ Hadianto, "Banyak Belajar Melelahkan Badan.", 33

${ }^{10}$ Bartholomew, Ecclesiastes, 17.
}

Bapa gereja Hieronimus yang hidup pada abad keempat. Ia mendorong seorang perempuan kaya untuk meninggalkan semua kekayaannya berdasarkan penafsirannya atas Pengkhotbah 1:2, "kesia-siaan belaka, kata pengkhotbah, kesia-siaan belaka, segala sesuatu adalah sia-sia." Bagi Hieronimus, segala sesuatu adalah sia-sia seperti yang dikatakan oleh Pengkhotbah sehingga harta kekayaan yang dimiliki perempuan itu juga tidak berarti dan seharusnya dibuang. 11 Apakah penafsiran Hieronimus tersebut tepat? Tentu saja tidak demikian. Oleh karena itu, menurut penulis, nuansa skeptis dan kesiasiaan dalam kitab ini perlu dipahami ulang dalam konteksnya sehingga para pembaca memperoleh pemahaman yang tepat akan maksud yang terkandung di dalamnya.

Sebenarnya apa yang dimaksud dengan kesia-siaan dalam kitab ini? Kata bahasa Ibrani yang dipakai untuk "sia-sia" dalam kitab ini adalah hebel. Secara literal, hebel berarti breath (nafas), breeze (hembusan angin), dan vapor (uap). ${ }^{12}$ Selain itu, kata hebel juga dapat berarti tidak berguna (uselesness) atau kekosongan (emptiness). Ada pula yang menerjemahkannya dengan

\footnotetext{
${ }^{11}$ Eka Darmaputera, Merayakan Hidup: Pemahaman Kitab Pengkhotbah Tentang KesiaSiaan Segala Sesuatu (Jakarta: Gunung Mulia, 2013), 4.

${ }^{12}$ Tremper Longman III, The Book of Ecclesiastes, The New International Commentary on the Old Testament (Grand Rapids: Eerdmans Publishing Company, 1998), 62.
} 
meaningless "tidak ada artinya." 13 Menurut Gerrit Singgih yang mengutip Michael Fox, pemakaian ungkapan hebel tersebut dalam kitab Pengkhotbah hendak menunjukkan:

Hidup ini sebagai sesuatu yang absurd, dalam arti ada jurang yang besar antara apa yang diharapkan dan apa yang dialami manusia. Kegiatan yang "absurd" adalah usaha yang terus menerus diulangi tetapi tidak rampungrampung seperti pekerjaan Sysyphus dalam mitologi Yunani, yang setiap kali mendorong batu ke puncak gunung, harus mengalami bahwa setelah hampir sampai ke puncak, batu itu meluncur ke bawah dan harus didorong lagi ke atas dan demikian seterusnya. Jurang besar ini tidak dianggap netral tetapi disoroti sebagai sesuatu yang tidak bermakna dan karena itu tidak adil.."14

Sekali lagi, kitab Pengkhotbah bukan berisi khotbah agar pembaca meyakini bahwa hidup, bekerja, dan belajar adalah sia-sia. Malahan, Pengkhotbah hendak mengajak manusia untuk merenung dan menimbang secara kritis segala aspek kehidupan ini, mulai tingkah laku manusia, termasuk makna dan tujuan hidup itu

\footnotetext{
${ }^{13}$ Singgih, Hidup Di Bawah Bayang-Bayang Maut: Sebuah Tafsiran Kitab Pengkhotbah, 20. Terkait dengan makna hebel ini, Eka Darmaputera memberikan sebuah contoh untuk dapat memahami makna kata tersebut. Jika seseorang sedang menjerang air, uap akan keluar menjelang air mendidih. Istilah hebel menunjuk sesuatu yang tidak mengandung apa-apa, sesuatu yang hampa. Seperti halnya uap yang tidak dapat dipegang, yang hilang begitu saja. Itulah ciri dari hebel. Lih. Darmaputera, Merayakan Hidup: Pemahaman Kitab Pengkhotbah Tentang Kesia-Siaan Segala Sesuatu, 14.

${ }^{14}$ Singgih, Hidup Di Bawah Bayang-Bayang Maut: Sebuah Tafsiran Kitab Pengkhotbah, 20-21.
}

sendiri. ${ }^{15}$ Pengkhotbah juga sebenarnya hendak memperlihatkan kepada pembacanya kenyataan itu apa adanya, realitas yang sesungguhnya terjadi dalam kehidupan ini. Meskipun terkadang kenyataan yang diungkapkannya begitu ekstrem dan sangat provokatif.

\section{Karunia Menulis Buku dan Banyak Belajar Itupun Sia-sia: Kritik Pengkhotbah atas Pengejaran Hikmat}

Pada bagian sebelumnya telah disinggung bahwa menurut pandangan tradisional, kitab Pengkhotbah ditulis pada era Salomo yaitu akhir abad $10 \mathrm{sM}$, pada periode sebelum pembuangan. Pandangan bahwa penulis kitab ini adalah Salomo juga dipopulerkan oleh Bapa gereja Jerome. ${ }^{16}$ Akan tetapi menurut sebagian besar ahli, beberapa petunjuk termasuk kata-kata yang termuat di dalamnya mengindikasikan bahwa kitab tersebut berasal dari periode Persia atau Helenis, misalnya penyebutan medinah sebagai tempat di mana para pembacanya hidup (Pkh. 5:7). Selain itu juga dapat ditemukan pengaruh pemikiran Yunani dalam tulisan tersebut sebagai hasil

\footnotetext{
${ }^{15}$ Hadianto, "Banyak Belajar Melelahkan Badan.", 34. Kata bahasa Ibrani Qohelet diartikan dengan Pengkhotbah karena dalam bahasa Indonesia itu berarti seorang yang memberikan khotbah. Padahal, tokoh yang sedang berbicara dalam kitab ini tidak bermaksud sekadar memberikan khotbah seperti yang kita kenal pada saat ini, tetapi lebih merupakan suatu refleksi kehidupan. Lih. Darmaputera, Merayakan Hidup: Pemahaman Kitab Pengkhotbah Tentang Kesia-Siaan Segala Sesuatu, 10.

${ }^{16}$ Bartholomew, Ecclesiastes, 44.
} 
dari pertemuan antara keyahudian dengan budaya Helenis. $^{17}$

Michael Fox mengatakan:

Koheleth's focus on individual experience, in particular the perception of pleasure, bears a significant resemblance to Hellenistic popular philosophy, whose central purpose was to find the way to individual happiness by the use of the powers of reason. The goal Koheleth sets himself in 2:3-to discover "what is good for men to do under the heavens during the few days of their life"-was central to Greek philosophy. ${ }^{18}$

Oleh karena adanya pengaruh pemikiran Helenis dalam kitab tersebut, sebagian besar ahli meyakini bahwa kitab Pengkhotbah ditulis atau lebih tepatnya disusun sekitar abad 3 atau 2 sM. ${ }^{19}$ Selain hal tersebut, beberapa bukti lain memang mengindikasikan bahwa tampaknya tidak mungkin bahwa Salomolah yang menulisnya seperti yang dipercayai oleh tradisi. Dari segi bahasa, teks kitab Pengkhotbah mengandung beberapa istilah dalam bahasa Aram. Padahal, bahasa Aram merupakan perkembangan bahasa Ibrani yang lebih kemudian, dan baru digunakan sepuluh abad setelah Salomo. Itu sebabnya, Craig Bartholomew memperkirakan kitab ini disusun pada sekitar tahun 167-164

\footnotetext{
${ }^{17}$ Michael V. Fox, Ecclesiastes: The JPS Bible Commentary (Philadelphia: Jewish Publication Society, 2004), xiv.

${ }^{18}$ Ibid, xi.

${ }^{19}$ Ibid, xiv.
}

sM. ${ }^{20}$ Hal yang senada dengan itu juga dikatakan oleh John Joseph Collins bahwa Salomo yang disebut dalam kitab Pengkhotbah berasal dari tradisi yang menghubungkan nama Salomo dengan kitab-kitab hikmat, bahkan kitab Kebijaksanaan Salomo sendiri juga baru disusun di Aleksandria pada periode intertestamental. ${ }^{21}$ Dengan adanya beberapa bukti penelitian terhadap kitab Pengkhotbah yang dilakukan para ahli, penulis juga setuju bahwa kitab Pengkhotbah tidak ditulis oleh Salomo (meskipun tidak menutup kemungkinan Salomo merupakan salah satu sumber atau tokoh hikmatinsipiratif yang mempengaruhi penulis atau penyusun kitab Pengkhotbah).

Dengan mengikuti pandangan para ahli yang berpendapat bahwa kitab Pengkhotbah ditulis sekitar abad 3 atau 2 sM, maka konteks sejarah dari kitab itu dapat ditelusuri lebih lanjut untuk dapat memperoleh maksud dan makna yang terkandung di dalamnya. Pada waktu itu, orang Yahudi berhadapan dengan sebuah budaya baru yaitu Helenisme (budaya Yunani). Berhadapan dengan budaya yang baru itu, sebagian orang Yahudi menolak mentah-mentah sementara sebagian yang

\footnotetext{
${ }^{20}$ Bartholomew, Ecclesiastes, 48-49.

${ }^{21}$ Collins, "Proverbs and Ecclesiastes.", 71 Kebijaksanaan Salomo dan Kitab Sirakh memang dianggap memiliki kedekatan. Lih. Bartholomew, Ecclesiastes, 10.
} 
lain menerimanya. ${ }^{22}$ Berhadapan dengan hal tersebut, pengkhotbah mengambil keputusan. Memilih yang satu bukan berarti melepaskan yang lain. Apakah ini berarti mengambil kedua-duanya? Apakah hal tersebut menjadi tipikal manusia (termasuk orang Indonesia)? Mengambil keduaduanya dapat berarti dua hal: bingung dalam menentukan pilihan atau tamak, tidak mau rugi. Akan tetapi, menariknya, pengkhotbah tidak termasuk di antara keduanya. Ia memilih untuk melihat keduanya secara kritis dan membuka peluang untuk menerima atau menolak serta mengkritisinya.

Lalu bagaimana dengan ungkapan "membuat banyak buku tidak akan ada akhirnya, dan banyak belajar melelahkan badan" yang dikatakan oleh penulis kitab Pengkhotbah (Pkh 12:12)? Bukankah orang yang menghasilkan banyak buku karena banyak belajar merupakan bagian dari anugerah atau karena Allah? Mengapa Pengkhotbah seolah-olah justru menganggap karunia tersebut adalah siasia? Apa latar belakang dan apa maksud yang terkandung di balik ungkapan tersebut?

Ungkapan "membuat banyak buku tidak ada akhirnya dan banyak belajar melelahkan badan" merupakan salah satu

\footnotetext{
${ }^{22}$ Bruggemann and Linafelt, An Introduction to the Old Testament: The Canon and Christian Imagination, 363.
}

kritik Pengkhotbah terhadap ajaran guruguru kebijaksanaan Yahudi pada saat itu yang menganggap bahwa hikmat merupakan sumber kebahagiaan manusia. Bagi kita selaku orang percaya pada masa kini umumnya akan mengagumi seorang penulis terkenal yang menghasilkan buku dan kemungkinan sambil bergumam "orang itu mempunyai karunia menulis dan belajar yang luar biasa." Akan tetapi, dalam konteks kitab Pengkhotbah, membuat banyak buku dan banyak belajar yang dimaksud di sini berkaitan erat dengan pengejaran akan hikmat. Anggapan populer tersebut dapat dijumpai pada bagian lain, misalnya dalam Kitab Amsal:

Berbahagialah orang yang mendapat hikmat, orang yang memperoleh kepandaian, karena keuntungannya melebihi keuntungan perak, dan hasilnya melebihi emas. Ia lebih berharga dari pada permata; apapun yang kauinginkan, tidak dapat menyamainya. Umur panjang ada di tangan kanannya, di tangan kirinya kekayaan dan kehormatan. Jalannya adalah jalan penuh bahagia, segala jalannya sejahtera semata-mata" (Ams. $3: 13-17){ }^{23}$

Benarkah demikian? Benarkah orang bijak dan berhikmat pasti bahagia? Salomo, sebagi penulis, melihat hikmat sebagai modal dasar dalam pencapaian hidupnya, lepas dari sisi kelam hidupnya itu sendiri. Hikmat merupakan cara Allah untuk

\footnotetext{
${ }^{23}$ Hadianto, "Banyak Belajar Melelahkan Badan.", 34
} 
membuat manusia dapat menggapai tujuan ilahi dalam rancanganNya. ${ }^{24}$

Dalam kenyataan hidup saat ini pun, ada begitu banyak orang pandai ( yang kita percaya adalah karunia Tuhan dan dibarengi dengan kerja keras orang tersebut), tetapi menggunakan kepandaiannya untuk meraup keuntungan dengan mengorbankan orang lain. Orang tersebut memang pandai tetapi tidak berhikmat. Lalu bagaimana nasib orang yang berhikmat? Fakta di lapangan menunjukkan bahwa orang-orang yang "sungguh-sungguh berhikmat" tersebut justru seringkali dianggap bodoh, dimusuhi, dan dijauhi. Sebagian besar dari mereka justru menjadi korban dan mengalami penindasan dari orang-orang pandai yang meskipun tidak berhikmat, dapat menikmati hidup dengan kekayaan yang dimilikinya. Sungguh kenyataan hidup yang ironis dan tidak sesuai dengan gambaran ideal yang dinyatakan dalam kitab-kitab hikmat. Itu sebabnya John Joseph Collins menyebut Pengkhotbah sebagai sosok yang kritis dan skeptis terhadap tradisi kebijaksanaan kuno. $^{25}$

\footnotetext{
${ }^{24}$ Harls Evan Siahaan, "HIKMAT SEBAGAI IMPLIKASI PENDIDIKAN KRISTIANI: REFLEKSI 1 RAJA-RAJA 3:1-15," DUNAMIS (Jurnal Teologi dan Pendidikan Kristiani) 1, no. 1 (2016): 15-30, accessed May 11, 2017, http://www.sttintheos.ac.id/ejournal/index.php/dunamis/article/view/99.

${ }^{25}$ Collins, "Proverbs and Ecclesiastes.", 71
}

Penulis kitab Pengkhotbah hendak mengatakan bahwa pengejaran hikmat adalah sesuatu yang sia-sia dan mengecewakan (Pkh 2:15-16; 7:23-29). Pengkhotbah menemukan bahwa, "tidak ada kenang-kenangan yang kekal baik dari orang yang berhikmat, maupun dari orang yang bodoh, sebab pada hari-hari yang akan datang kesemuanya sudah lama dilupakan. Dan, ah, orang yang berhikmat mati juga seperti orang yang bodoh! (Pkh. 2:16). Pengkhotbah bergumul lalu menyadari bahwa semakin keras ia berusaha memahami makna hidup, semakin ia menyadari bahwa hal tersebut adalah siasia. Sebelum ia menyadari makna hidup, kematian telah datang menjemputnya.

Dalam Pengkhotbah 12:12 dikatakan, "Lagipula, anakku, waspadalah! Membuat banyak buku tak akan ada akhirnya, dan banyak belajar melelahkan badan." Pengkhotbah mengajak murid atau pembacanya untuk bersikap kritis dan waspada. Kata "anakku” kemungkinan besar menunjuk kepada murid Qohelet. ${ }^{26}$ Menurut Longman, sebagian besar ahli berpendapat bahwa terdapat nuansa pengajaran dari seorang guru kepada muridmuridnya memang terlihat dalam kitab

\footnotetext{
${ }^{26}$ Singgih, Hidup Di Bawah Bayang-Bayang Maut: Sebuah Tafsiran Kitab Pengkhotbah, 226.
} 
Pengkhotbah. ${ }^{27}$ Menurut Gerrit Singgih, jika orang tersebut adalah murid Qohelet, maka yang diinginkan hanyalah supaya orang hanya memegang satu tulisan yaitu tulisan Pengkhotbah dan hanya mempelajari itu saja. Tidak usah dipusingkan dengan berbagai ajaran yang berkembang pada waktu itu karena sejak awal, Pengkhotbah hendak mengatakan bahwa segala jerih payah yang dilakukan manusia untuk memahami makna hidup adalah sia-sia. ${ }^{28}$ Hal yang sama diungkapkan oleh Bartholomew. Menurutnya, konteks peringatan yang diberikan Qohelet kepada muridnya terkait dengan umat Israel yang dicobai oleh filsafat Yunani. ${ }^{29}$ Hal tersebut menjadi sebuah pembelajaran penting. Banyak orang bergumul dan berusaha mencari arti hidup. Bahkan ada orang yang dengan lelah memikirkan dan membayangkan apa yang akan terjadi hari ini dan besok. Ada banyak orang yang setiap hari merasa kuatir dengan hidupnya. Banyak orang bergumul dengan pertanyaan yang menggelisahkan diri sendiri. Semakin orang bergumul dan belajar untuk mencari jawaban atas pertanyaan tersebut, semakin ia menemukan bahwa tidak ada jawaban yang

\footnotetext{
${ }^{27}$ III, The Book of Ecclesiastes, The New International Commentary on the Old Testament, 58.

${ }^{28}$ Singgih, Hidup Di Bawah Bayang-Bayang Maut: Sebuah Tafsiran Kitab Pengkhotbah, 227.

${ }^{29}$ Bartholomew, Ecclesiastes, 369.
}

pasti. Sia-sia. Semua orang pasti mati tetapi hidup setelah kematian pun adalah sebuah misteri yang tidak terpecahkan. Manusia tidak dapat mengetahui atau mengontrol kehidupan ini. Jadi "untuk apa seseorang mengejar hikmat? Sebuah usaha menjaring angin." Demikian kata Pengkhotbah.

Manusia tidak dapat mengontrol segala sesuatu di luar dirinya. Segala usaha manusia untuk dapat meraihnyanya tidak akan berhasil. Sia-sia belaka. Siapa yang dapat mengontrol segala sesuatu? Hanya Tuhan sendiri. Jika semuanya itu sia-sia karena hanya Tuhan yang dapat mengaturnya, lalu apa yang harus dilakukan manusia? Pengkhotbah mengajak pembaca untuk menjalani hidup ini saja, karena hidup ini adalah anugerah Allah. menikmati hidup. "Enjoy aja" menurut sebuah bahasa iklan. Tetapi jangan buru-buru menuduh Pengkhotbah sebagai "golongan libertinian" yang menganjurkan gaya hidup bebas, menikmati hidup sebebas-bebasnya sebelum mati. Tidak. Anjuran Pengkhotbah tersebut tidak berhenti sampai di sini. Masih ada kelanjutannya.

\section{KESIMPULAN}

Ungkapan "banyak belajar melelahkan badan" (Pkh 12:12) oleh para ahli dianggap sebagai bagian dari ayat 9-12 yang diyakini merupakan tambahan. Karena bagian tersebut merupakan kesatuan, maka tidak boleh dilupakan kedua ayat terakhir yang 
merupakan puncak dari perenungan sang Qohelet yaitu Pengkhotbah 12:13-14, "Akhir kata dari segala yang didengar ialah: takutlah akan Allah dan berpeganglah pada perintah-perintah-Nya, karena ini adalah kewajiban setiap orang. Karena Allah akan membawa setiap perbuatan ke pengadilan yang berlaku atas segala sesuatu yang tersembunyi, entah itu baik, entah itu jahat."

Ternyata, tidak semuanya sia-sia menurut Pengkhotbah. Ada satu yang tidak, yaitu Allah. Manusia memang tidak bisa memilih kehidupan yang lain, hanya kehidupan inilah satu-satunya yang Allah berikan. Oleh karena itu yang bisa dilakukan adalah menerimanya dan memahaminya dalam kesadaran bahwa hidup ini adalah karunia (anugerah) Allah. Pengkhotbah mengajak orang untuk menikmati hidup pemberian Allah. Kewajiban setiap orang tersebut juga meliputi bagaimana menikmati dan merayakan kehidupan pemberian Allah. Setiap orang diajak untuk menjalaninya dengan takut akan Allah. Inilah puncak perenungan dari Pengkhotbah. Takut akan Allah berarti tunduk kepada Allah. Tunduk kepada Allah karena hanya Allahlah yang tahu segala sesuatu dan hanya Dialah yang tidak sia-sia.

Orang boleh belajar dan membuat buku sebanyak mungkin untuk merengkuh hikmat dan pengetahuan (Pkh. 12:12). Akan tetapi hal tersebut mustahil dapat dilakukan, semuanya sia-sia. Hal tersebut sekaligus menandakan kekurangan dan kefanaan manusia. Manusia hanya dapat menikmati semua hikmat dan pengetahuan dalam dunia ini untuk sementara waktu. Ketika Yang Mahakuasa mengambil hidup dan waktu yang telah dianugerahkan, maka berakhirlah pengetahuan sesorang yang tertampung di dalam otak manusia. Ketika manusia mati, maka aktivitas otak pun berhenti. Berhadapan dengan kenyataan tersebut, manusia diajak untuk menikmati waktunya karena segala sesuatu ada waktunya. Bahkan bukan hanya itu, manusia harus mempertanggungjawabkan hidup dan waktu yang telah diberikan Allah (Pkh. 12:14). Dengan kata lain, Pengkhotbah mengajak pembaca untuk menikmati hidup dengan bertanggung jawab.

Pengkhotbah tidak menganjurkan hidup yang bebas sebebas-bebasnya. Pengkhotbah mengajak manusia untuk kembali kepada Allah. Takut akan Allah dan berpegang pada perintah-perintahnya. Dengan demikian, ungkapan "banyak belajar melelahkan badan" tidak dimaksudkan untuk dipakai sebagai pembenaran terhadap sifat malas. Sebaliknya, ungkapan tersebut dapat diartikan sebagai teguran bagi orangorang yang merasa diri bijak (karena sudah 
banyak belajar). Mereka kadang lebih percaya pada akal budi dan kepandaiannya daripada kepada Allah.

\section{DAFTAR PUSTAKA}

Bartholomew, Craig G. Ecclesiastes. Philadelphia: Baker Academic, 2014. Bruggemann, Walter, and Tod Linafelt. An Introduction to the Old Testament: The Canon and Christian Imagination. Louisville: Westminster John Knox Press, 2012.

Collins, John. "Proverbs and Ecclesiastes." In Knox Preaching Guides, edited by John H. Hayes. Atlanta: John Knox Press, 1980.

Darmaputera, Eka. Merayakan Hidup: Pemahaman Kitab Pengkhotbah Tentang Kesia-Siaan Segala Sesuatu. Jakarta: Gunung Mulia, 2013.

Dillard, Tremper Longman III dan Raymond B. An Introduction to the Old Testament. 2nd ed. Grand Rapids: Zondervan, 2006.

Fox, Michael V. Ecclesiastes: The JPS Bible Commentary. Philadelphia: Jewish Publication Society, 2004.
Hadianto, Jarot. "Banyak Belajar Melelahkan Badan." Wacana Biblika Vol.9, no. 1 (Januari-Maret) (2009).

III, Tremper Longman. The Book of Ecclesiastes, The New International Commentary on the Old Testament. Grand Rapids: Eerdmans Publishing Company, 1998.

Siahaan, Harls Evan. "HIKMAT SEBAGAI IMPLIKASI PENDIDIKAN KRISTIANI: REFLEKSI 1 RAJARAJA 3:1-15." DUNAMIS (Jurnal Teologi dan Pendidikan Kristiani) 1, no. 1 (2016): 15-30. Accessed May 11, 2017. http://www.sttintheos.ac.id/ejournal/index.php/dunamis/article/vie w/99.

Singgih, Emanuel Gerrit. Hidup Di Bawah Bayang-Bayang Maut: Sebuah Tafsiran Kitab Pengkhotbah. Jakarta: PK Gunung Mulia, 2001. 